\title{
ВИКОРИСТАННЯ ТЕХНОЛОГІЙ ВІРТУАЛЬНОЇ РЕАЛЬНОСТІ В СУЧАСНИХ КОНЦЕРТНИХ ШОУ
}

\section{- Кириченко Альона Олегівна}

\section{- Аспірантка,} ORCID: 0000-0002-6237-832X, e-mail: AlenaKiri4enko@gmail.com, Київський національний університет культури і мистецтв, вул. Є. Коновальця, 36, Київ, Україна, 01133

\section{- Для цитування:}

Кириченко, А.О. (2020). Використання технологій віртуальної реальності в сучасних концертних шоу. Питання культурології, (36), 206-218. doi: https://doi.org/10.31866/24101311.36.2020.221068.

\section{- Анотація}

Мета статті - схарактеризувати сучасні концертні шоу в контексті використання в них технологій віртуальної реальності. Методологія дослідження ґрунтується на застосуванні міждисциплінарного підходу до аналізу концертних шоу, теоретичного підходу - для вивчення наукової літератури; аналітичного та компаративного - для визначення впливу технологічної складової на режисуру сучасних шоу. Наукова новизна полягає в тому, що вперше розглянуто віртуальні технології, інтегровані в концертне шоу. Висновки. Технології віртуальної / доповненої реальності, поступово входячи у всі сфрери нашого життя: від медицини, освіти, науки до мистецтва, архітектури та дозвіллєвої діяльності людини, вже перестають асоціюватися з чимось надновим. Концерне шоу з допомогою надсучасних технологій може поєднувати у собі різні види мистецтв, а тому має потужний потенціал впливу на глядача. На прикладі конкретних концертних шоу та виступів артистів презентовано механізм «вплетення» технологій віртуальної / доповненої реальності в сценічний простір. Розглянуто поняття віртуальної, доповненої та змішаної реальності. Зазначено, що 3 потужним розвитком інформаційно-комунікаційних технологій можливе поєднання усіх комп'ютерних технологій в єдину розширену реальність. Кінець XX ст. ознаменувався появою віртуального гурту, а вже початок XXI ст. - появою віртуальних артистів-вокалоїдів та відтворенням віртуальних копій померлих артистів, що дає підстави констатувати можливості впровадження новітніх комп'ютерних технологій у концертні шоу. Акцентується увага на тому, що використання технологій стає не лише «ефектом заради ефекту», а й підкреслює чи доповнює ідейно-тематичну спрямованість шоу. Визначною подією в індустрії розваг сьогодення стало створення українськими та закордонними артистами віртуальних онлайн-концертів. Концертні шоу трансформуються під впливом віртуальних технологій, тобто віртуалізуються, 
щоб бути актуальними і відповідати викликам часу та запитам вибагливої глядацької аудиторії.

Ключові слова: концертне шоу; V / AR / MR / XR; вокалоїд; віртуальний онлайнконцерт; індустрія розваг

\section{- Вступ}

Концертне шоу за своєю сутністю є однією із форм культурно-дозвіллєвої діяльності, еволюція яких - безперервний процес переходу від минулого до сьогодення, від сьогодення до майбутнього. Цей стан формується і підтримується не лише загальними тенденціями соціокультурного прогресу суспільства і світової культурної цивілізації, а й внутрішніми закономірностями розвитку культурно-розважальної сфери. Остання здатна надавати широкі можливості для відпочинку та розваг. Однак помилково вважати, що концертні шоу виконують тільки гедоністичну функцію, адже видовище як феномен культури необхідне, зокрема, й для естетичного виховання громадян. Повноцінний розвиток молоді та її інтеграція в суспільстві неможливі поза культурою, відтак, видовище є чинником, що сприяє фрормуванню художніх і творчих інтересів молодого покоління. Більше того, концертні шоу сприяють налагодженню діалогу між різними культурами і поколіннями, появі нових талантів у молодіжному середовищі тощо. Сьогодні індустріальне виробництво концертних шоу на Заході досягло колосальних розмірів і результатів, і не лише завдяки постійному прагненню до масштабності, помпезності, декоративності видовища, а й надзвичайно високому рівню технічної оснащеності. Саме можливості техніки призвели до того, що функціонування концертних шоу виходить на новий технологічний рівень. Тому виникає необхідність спростувати цю думку, здійснивши огляд відомих концертних шоу на предмет використання в них новітніх технічних досягнень, які $€$ передумовою і результатом розвитку культури.

Проблематика застосування технологій віртуальної реальності у концертних шоу та загалом віртуалізації культури не отримала широкого висвітлення у працях українських і закордонних дослідників. Цей розділ знання лише частково перебуває у полі зору академічної науки, хоча певні напрацювання все ж варто відзначити. Зокрема, це дослідження В. Волинець (2019), М. Муртазіної (Муртазина, 2012), М. Моженко й О. Прядко (2018) та ін. Нові технології у сучасному художньо-постановочному процесі розглядають Л. Михайлов (2007), Г. Тихоновська (Тихоновская, 2016), К. Юдова-Романова (2017) та ін. Видовищні форми в мистецько-культурному просторі досліджені К. Станіславською (2016). Проблему загальної шоутизації суспільства висвітлює у своїх роботах Н. Дубовик (2010), шоу-технології як форму соціальної комунікації - А. Скрипка (2015). Телевізійні і танцювальні шоу-програми є об'єктом вивчення у наукових розвідках О. Бойко (2017), Т. Совгири (2014) та ін. Однак досліджень, безпосередньо присвячених сучасним концертним шоу як прояву віртуалізації, на сьогодні майже немає, відтак це визначає актуальність статті. 


\section{- Мета статті}

Мета статті - схарактеризувати сучасні концертні шоу в контексті використання в них технологій віртуальної реальності. Методологія дослідження ґрунтується на застосуванні міждисциплінарного підходу до аналізу концертних шоу, теоретичного підходу - для вивчення наукової літератури; аналітичного та компаративного - для визначення впливу технологічної складової на режисуру сучасних шоу. Наукова новизна полягає в тому, що вперше розглянуто віртуальні технології, інтегровані в концертне шоу.

\section{- Виклад матеріалу дослідження}

Шоу - особливе синтетичне мистецтво, що поєднує у собі різні види мистецтв: від живопису, опери, балету, кінематографра до комп'ютерної графріки. Завдяки цьому шоу має значно більше можливостей впливу на глядача в сучасному світі, ніж будь-яке інше мистецтво. В шоу швидше, ніж в інших видах мистецтва, можна простежити актуальні тенденції та зміни культурних парадигм сучасного суспільства. Підтвердженням цієї тези є застосування в шоу досягнень сучасної науки: зі сфрери штучного інтелекту, робототехніки, технологій віртуальної і доповненої реальності та ін. Ці технології є вкрай складними, і «вплести» їх у тканину сценічного простору інколи буває доволі проблематично, та все ж режисерів приваблює ця ідея, бо мистецтво шоу мусить бути сучасним й інноваційним, аби задовольнити вибагливого глядача.

Термін «віртуальний» міцно закріпився в сучасному науковому лексиконі. Віртуальність (від. лат. virtualis - «можливий») - це об'єкт або стан, які реально не існують, але можуть виникнути за певних умов (Кириленко та ін., 2018, с. 28). Заведено розрізняти доповнену, змішану і віртуальну реальність. Так, віртуальна реальність (англ. Virtual Reality, VR) - це штучна реальність, згенерована комп'ютером, у яку глядач повністю занурюється з допомогою візуальних, звукових і тактильних ефректів (Віртуальна реальність, 2020). Ця технологія пропонує повне занурення в середовище, яке заміщує реальне. Терміном «доповнена реальність» (англ. Augmented Reality, AR) визначають комп'ютерні програми, спрямовані на доповнення оточуючої людей реальності певними віртуальними елементами (Віртуальна реальність, 2020). Змішаною реальністю (англ. Mixed Reality, MR) іноді називають гібридну реальність, що є злиттям реальних і віртуальних світів для створення нових середовищ і візуалізації, де фрізичні та цифрові об'єкти співіснують і взаємодіють у режимі реального часу (Змішана реальність, 2020). У цьому разі в реальний світ додаються віртуальні предмети, прикріплені до свого місця в просторі для того, щоб користувач сприймав їх як реальні. Ключові моменти в змішаній реальності - максимізація правдоподібності і можливість взаємодії з віртуальним об'єктом, який «живе» в реальному світі. Поряд з цими поняттями вживають також узагальнений термін «розширена реальність» (англ. Extended Reality, XR), що охоплює всі можливі фрорми зміненої комп'ютером реальності, включно з доповненою, змішаною і віртуальною. Тому із прискореним подальшим розвитком інформаційно-комунікаційних технологій прогнозують «злиття комп'ютерних реальностей» в єдиному продукті формату XR. 
Вищеназвані технології наразі активно використовують не лише у комп'ютерних іграх, медицині чи рекламі, а й у шоу-програмах. При цьому технологія VR у шоу повною мірою не використовується через складність реалізації, a технологія AR, яка найчастіше передбачає необхідність використання екрана (телефона, планшета, телевізора) чи VR-окулярів, широко застосовується у видовищних заходах. Так, у шоу Світлани Лободи "SUPERSTAR SHOW» (2018) була використана технологія доповненої реальності - 3 допомогою спеціального додатка, який артистка перед концертом попросила глядачів завантажити на свої смартфони. Наводячи камеру мобільного телефона на сцену, можна було побачити додаткові графічні елементи: гігантську артистку, а над нею - літаючі об'єкти та багато інших спецефектів.

Аналогічно в концертних шоу групи «U2» під назвою «EXPERIENCE + INNOCENCE» (2018) була використана технологія доповненої реальності. Через заздалегідь інстальований мобільний додаток глядач перед початком шоу вже міг споглядати видовищний ефект: айсберг, який поступово тане та заповнює водою глядацький зал. Цю картину можна було побачити, навівши свій смартфон на двосторонній відеоекран (елемент сценографії). При виконанні першої пісні шоу фрронтмен гурту «U2» Боно на екранах телефонів глядачів втілювався в гігантського аватара, який підносився над аудиторією. Рухи співака, який знаходився на сцені, перегукувалися з його віртуальним аватаром, що давало цікавий ефект синтезу віртуального і реального зображення (Hitti, 2018).

Варто зазначити, що інтерактив з мобільними телефонами - дуже слушна думка для постановників шоу, адже глядач все одно використовує камеру, щоб зафріксувати виступ артиста. То чому б не створити додаткові ефректи, які зможуть не лише здивувати глядача, а й містять змістове навантаження як окремий видовищний ефект шоу.

В телевізійному форматі одними з перших, хто використав у своєму виступі ефект доповненої реальності були Мадонна та колумбійський співак Малума. Головною особливістю цього ефекту $є$ те, що його можуть бачити тільки телеглядачі чи глядачі на спеціальних трансляційних кранах у концертному залі. Під час прямої трансляції премії «Billboard Music Awards 2019» на сцені з допомогою комп'ютерної графіки двійниками Мадонни були відтворені її образи з кліпу на пісню «Medellín». Чотири «віртуальні» Мадонни з'являлися, а потім зникали зі сцени, танцюючи поряд з Малумою та з реальною Мадонною. Це створювало ілюзію миттєвого переміщення співачки на сценічному майданчику (Madonna, 2019).

Також у 2019 році на щорічній премії «МУЗ-ТВ» технологія доповненої реальності була інтегрована в кілька номерів шоу. Під час виступу Макса Барських з піснею «Неземна», гігантська «неземна» дівчина-гуманоїд у фріналі пісні спустилася зі стелі (з неба), щоб обійняти артиста; у номері Світлани Лободи балетом були віртуальні 3D-скелети; Діма Білан зустрівся зі своєю віртуальною копією, яка танцювала поруч з артистом. Як зазначили у команді режисера цього шоу Олега Боднарчука: «AR дає можливість істотно розширити наш реальний світ, доповнивши його віртуальною графікою, даючи телеглядачам можливість бачити диво на картинці, графічні елементи в реальному часі, одночасно даючи 
режисеру змогу розповісти цікаву історію завдяки взаємодії артиста з віртуальною графрікою і відеорядом на екранах» (Muz-tv, 2019).

Церемонія відкриття 45 міжнародного чемпіонату з професійної майстерноcті «WorldSkills Kazan 2019» відзначилася інтерактивністю та новими технічними ноу-хау, впровадженими вперше на стадіоні «Казань Арена». Була використана технологія доповненої реальності на всі 360 градусів, завдяки чому глядачі на трибунах змогли побачити AR-ефекти через екрани своїх ґаджетів, а також на інформаційних екранах стадіону. Сигнали на екранах попереджали учасників церемонії про появу чергового віртуального ефекту. Як зазначає режисерпостановник церемонії Олексій Сєченов: «Робота над церемоніями світового чемпіонату WorldSkills стала справжнім викликом для нашої команди. Ми спробували відобразити в церемонії найцікавіші розробки нашого часу, і тому запросили тих, хто їх створює і змінює стиль життя кожного з нас. Під розповіді винахідників, які створили розумний годинник або людиноподібного робота, пекар на очах публіки випікатиме хліб. Різні епохи знайдуть гармонію в художньому просторі церемонії. Ми хочемо, щоб глядачі не лише отримали естетичне задоволення від шоу, а й задумалися про виклики сучасності, уявили, як виглядатиме наше життя через 10, 50 і навіть 100 років!» (Пресс-служба Оргкомитета 45-го мирового чемпионата WorldSkills Kazan 2019, 2019).

В шоу було передбачено кілька епізодів. Концепція, яка поєднувала їх, це ода становленню людини-професіонала. Автори представили чотири етапи творчого і професійного пошуку - «Пізнання», «Експеримент», «Удосконалення» і «Створення». На кожному з цих етапів спікер-професіонал, який володіє досягненнями, визнаними на світовому рівні, розповів свою історію, проілюстровану хореографічним номером і роботою VR-художника наживо, малюнок якого з'являвся на екранах-трикутниках у центрі стадіону. Один з епізодів шоу супроводжувався величезною віртуальною картиною - китом, який «пропливав» навколо чаші стадіону. Композицію створив данський VR-художник Мартін Небелонг - один з провідних VR-художників у світі. У фінальному епізоді була задіяна «Софія» (робот-андроїд), яка вийшла на сцену зі своїм творцем Девідом Хенсоном і розмірковувала про взаємозв'язок сучасних технологій і людини. «Технологія - це просто інструмент для вивчення світу. Разом ми зможемо подолати міжзоряні відстані і створити процвітаюче і гармонійне майбутнє для всіх», - поділилася своїм баченням розвитку стосунків між роботом і людиною робот-андроїд «Софрія» (Пресс-служба Оргкомитета 45-го мирового чемпионата WorldSkills Kazan 2019, 2019).

Ефект віртуальної реальності в сценічному просторі спробував відтворити й згаданий вище український режисер Олег Боднарчук на церемонії нагородження «M1 Music Awards. III елемент» у 2017 році. У геометричному просторі на вершині унікальної споруди співак Alekseev розпочав виконання свого хіта «Відчуваю душею». Високотехнологічний пристрій з умовною назвою «рука» не що інше, як робот KUKA, на вершині якого був закріплений артист. Графіки створили віджеїнг для екранів відповідно до рухів артиста в стилі оп-арт, а запрограмована технологічна установка повертала артиста на 360 градусів, при цьому виконавець співав наживо, перебуваючи в позиції головою вниз на сцені, 
що є складним трюком. Над створенням цього номеру команда працювала пів року. Як зазначив режисер: «Сьогодні сценічна оригінальна технологія - невід'ємна частина шоу і локомотив в його розвитку» (Боднарчук, 2020, с. 18).

VR-технології використовують не лише як доповнення до виступів артистів, а й для створення їх віртуальних аналогів. Наприклад, британський гурт «Gorillaz», який згодом вписав своє ім'я в книгу рекордів Гіннеса як «найуспішніший віртуальний гурт», був заснований у 1998 році музикантом Деймоном Албарном і художником коміксів Джеймі Хьюлетом. Гурт складається з чотирьох намальованих персонажів, кожен із яких має свою біографію. Після випуску двох мегауспішних альбомів, у 2005 році гурт вперше відправився в світове турне. На перших концертах музиканти ховалися за екранами з анімацією, демонструючи глядачам тільки свої тіні. Лише згодом почали використовувати голограмні зображення, але це виявилося дорогим задоволенням і до таких спецефектів вдавалися лише на масштабних шоу і церемоніях нагородження. Так, на сцені премії «Grammy» гурт «Gorillaz» виконав хіт «Feel Good Inc.», та підіграв Maдонні під час виконання пісні «Hung Up». Це стало можливим завдяки програмі Musion Eyeliner System (дослівно «Система музичної підводки для очей»), використаної для створення тривимірних голографічних мультперсонажів Gorillaz, які виступали на сцені, - фактично з'являлися на екрані, що перекривав дзеркало сцени (Юдова-Романова, 2019).

Японська компанія «Crypton Future Media» створила віртуальну співачку Міку Хацуне - перше візуальне втілення співака, яке мало шалений успіх у всьому світі. Зовнішність співачки є характерною для японської культури - це типовий персонаж з аніме: великі очі, бірюзове волосся. Але, на відміну від британського гурту «Gorillaz», де реальні музиканти наживо виконують свої пісні, Міку - перший вокалоїд та поп-ідол. Її голос повністю синтезований з допомогою однойменної комп'ютерної програми Vocaloid - синтезатора голосу, який створює пісні без участі живого виконавця. Програма надає можливість завантажувати готові мелодії, ноти майбутньої вокальної партії і тексти пісень, а потім з допомогою голосового сховища (бібліотеки), де збережені голоси реальних людей (акторів, дикторів, професійних вокалістів), озвучувати завантажений текст. Розробкою технології займалися в іспанському університеті Pompeu Fabra за фрінансової підтримки японської компанії «Үamaha». Міку Хацуне не єдиний вокалоїд, - компанією раніше були створені Мейко (жіночий голос) і Каіто (чоловічий). Сьогодні є вже кілька десятків вокалоїдів і практично у кожного з них своя армія прихильників.

Виступ віртуального виконавця - складне з точки зору техніки шоу, в якому музиканти на сцені грають на музичних інструментах поряд з об'ємною проєкцією артиста, при цьому використовуються різнокольорові лазери, світлові ефекти. Новітні комп'ютерні технології дають можливість не лише створити віртуальних персонажів, а й «оживити» померлих співаків, акторів, артистів. Першим, кого відтворили з допомогою голографічних технологій, був легендарний американський репер Тупак Шакур - один з найвпливовіших хіп-хоп-виконавців в історії музики. На фестивалі «Coachella» в 2012 році віртуальний Тупак приголомшив публіку своєю появою разом із зірками хіп-хопу Доктором Дре і Снуп 
Догом, заспівавши з ними дві пісні. Цифрове зображення Майкла Джексона було відтворене на церемонії «Billboard Music Awards» в 2014 році. Віртуальний Майкл заспівав пісню «Slave to the Rhythm» з його посмертного альбому «Хscape».

Віртуальні онлайн-концерти - це теж виразний приклад застосування шоу-бізнесом новітніх розробок у сфрері віртуальної реальності. Так, у період локдауну артисти змушені були скасувати свої шоу, концертні турне і перейти в онлайн-середовище. Американська співачка Біллі Айліш, корейський гурт «BTS» та український співак Олег Винник створили масштабні віртуальні онлайн-концерти. Шалено популярний південнокорейський чоловічий попгурт «BTS» першим запропонував віртуальний фрормат концерту своїм прихильникам. За масштабністю та видовищністю цей виступ можна повноправно назвати віртуальним онлайн-шоу. Виступ гурту відбувся у червні 2020 року і тривав півтори години. За цей час музиканти виконали 12 пісень наживо, пересувалися і виступали на різних майданчиках: 2 сцени і 5 кімнат, стилізовані під різні настрої з масштабними декораціями. В кількох номерах навіть був задіяний оркестр і десятки танцівників. Трансляція велась з шести видів камер, тому глядачі мали змогу перемикатися між камерами та обирати найкращий ракурс для перегляду. Для моделювання реального середовища виступу артистів на екрани було виведено зображення деяких прихильників, які в реальному часі дивилися цей концерт і підтримували своїх кумирів. Концерт встановив світовий рекорд за кількістю глядачів - виступ артистів подивилися 756 тис. людей з понад 100 країн світу (Millman, 2020).

Єдине в Україні online-VR шоу Олега Винника транслювалося у липні 2020 року в прямому етері з найбільшого майданчика України НСК «Олімпійський». На стадіоні було встановлено 54-метрову сцену, потужний звук та світло. Огляд на 360 градусів давав змогу побачити все, що відбувалося навколо, що максимально наближало глядача до відчуття реального перебування на майданчику. У створенні шоу використали VR-, AR-технології, таким чином музично-інтерактивний захід об'єднав реальне з віртуальним. Фан-зона і трибуни були заповнені віртуальними глядачами. Унікальні візуальні та спецефекти супроводжували кожну пісню. Потужні віртуальні можливості були продемонстровані на початку концерту, коли коридори НСК перетворилися для глядачів на метро, в яке «віртуально» спустився співак перед виходом на сцену.

Отже, нові технології формують нову реальність, усувають більшість фрізичних бар'єрів, дають додаткові можливості для розвитку. Межа між фізичним і цифрровим світом стає все менш помітною. Сьогодні відбувається створення нового виду реальності, в якій, можливо, доведеться жити, вчитися, грати, працювати сучасному та майбутнім поколінням.

\section{- Висновки}

Потужний розвиток технологій не може не позначитися на індустрії розваг, адже ця індустрія реагує на прогрес в пришвидшеному темпі. Оскільки ключовими характеристиками розваг є емоції, враження та задоволення, які супроводжують процес розваги або є ії результатом, то артисти та режисери концертних 
шоу мають на меті здивувати свого глядача, створити щось новітнє, подарувати йому вражаючі емоції. Віртуальна, доповнена та розширена реальності переміщають глядачів з реального у світ ілюзорний, вигаданий. I це може використовуватися як спецефект, ефект заради ефекту, щоб здивувати, а може бути важливим ідейним рішенням, що розкриє ідею номеру, шоу. Також у складний період дії карантинних заходів віртуальні технології дали змогу багатьом людям отримати позитивні емоції від віртуальних шоу артистів.

Сучасні концертні шоу, що використовують новітні технологічні досягнення, перебувають на стадії еволюції і намагаються відповідати викликам часу. Однак позитивний результат їх впливу на глядача залежить від ціннісно-моральних орієнтирів артистів, продюсерів, режисерів та інших спеціалістів, дотичних до творення шоу. Тобто від їх світогляду, професійної майстерності, творчого потенціалу, що ґрунтується на знаннях про роль мистецтва у цифрову епоху, про культурні пріоритети і міжкультурну комунікацію. Лише за цих умов сучасні концертні шоу можуть стати не просто визначним явищем культури, а й потужним інструментом соціокультурного розвитку, не просто основою художньої культури, а безпосереднім вираженням естетичного й емоційного розуміння реальності.

Зважаючи на складність розглянутого явища, подальшого дослідження потребують питання формування глядацької культури на концертній естраді.

\section{- Список використаних джерел}

Боднарчук, О. В. (2020). Как создать грандиозное шоу. Безуглий М. О. ФОП .

Бойко, О. С. (2017). Телевізійні танцювальні шоу в Україні: історія і сучасність. Вісник Київського національного університету культури і мистецтв. Серія "Мистецтвознавство", 36, 66-76.

Віртуальна реальність. (2020, 5 квітня). В Вікіпедіï. https://cutt.ly/ghGsTmh.

Волинець, В.О. (2019). Віртуалізація культури в добу інтернет-технологій [Автореферат дисертації кандидата культурології, Київський національний університет культури і мистецтв].

Дубовик, Н. (б.г.). Шоутизация современной культуры. DOKPLAYER, 224-233. Взято 20 жовтня 2020 р. 3 https://docplayer.ru/36670939-Shoutizaciya-sovremennoykultury.html.

Змішана реальність. (2020, 20 травня). В Вікіпедіï. https://cutt.ly/ShFToS4.

Кириленко, К., Кундеревич, О., \& Бойко Л. (2018). Філосоорія культури: Словник. Агентство "Україна".

Михайлов, Л.Н. (2007). Создание современного эстрадного зрелища: принципы художественного оформления [Автореферат диссертации кандидата искусствоведения, Российская академия театрального искусства].

Моженко, М.В., \& Прядко, О.М. (2018). Віртуальна реальність: від технології до мистецтва. Мистецтвознавчі записки, 34, 112-122.

Муртазина, М.Ш. (2012). Виртуальная культура как френомен глобализации: философско-культурологическое осмысление [Автореферат диссертации кандидата философских наук, ФГБОУ ВПО "Забайкальский государственный университет"]. 
Пресс-служба Оргкомитета 45-го мирового чемпионата WorldSkills Kazan 2019. (2019, 22 августа). Роботы, киты и клятвы: в Казани прошла церемония открытия 45-го мирового WorldSkillsKazan 2019. https://worldskills2019.com/ru/media/ news/roboty-kity-i-klyatvy-v-kazani-proshla-ceremoniya-otkrytiya-45-go-mirovogoworldskills-kazan-2019/index.html.

Скрипка, А. О. (2010). Шоу-технології як фрорма соціальної комунікації. [Авторефрерат дисертації кандидата соціологічних наук, Харківський національний університет імені В. Н. Каразіна].

Совгира, Т. І. (2014). Шоу як фрорма організації масового дозвілля. Перспективні напрямки світової науки, 1, 65-67.

Станіславська, К. І. (2016). Мистецько-видовищні фрорми сучасної культури [Монографрія] (2-е вид). Національна академія керівних кадрів культури і мистецтв.

Тихоновская, Г. С. (2016). Технологические аспекты реализации элемента зрелищности в культурно-досуговых программах. Вестник Московского государственного университета культуры и искусств, 5(73), 155-163.

Юдова-Романова, К. В. (2017). Технічні засоби оформлення сценічного простору. Видавничий центр КНУКіМ.

Юдова-Романова, К., Стрельчук, В., \& Чубукова, Ю. (2019). Режисерські інновації у використанні технічних засобів і технологій у сценічному мистецтві. Вісник Київського національного університету культури і мистецтв. Серія: Сценічне мистецтво, 2(1), 52-57.

Hitti, N. (2018, May 9). Giant augmented reality avatar of Bono appears on Es Devlin's U2 stage set. https://www.dezeen.com/2018/05/09/es-devlin-augmented-realityavatar-bono-u2-set-design/.

Madonna. (2020, February 1). Madonna \& Maluma - Medellín (2019 Billboard Music Awards) [Video]. YouTube. https://www.youtube.com/watch?v=9Z1GdMuC9E8.

Millman, E. (2020, June 16). BTS Just Proved That Paid Livestreaming Is Here to Stay. RollingStone. https://www.rollingstone.com/pro/news/bts-paid-livestream-bangbang-con-1015696/.

Muz-tv. (2019, 13 июня). Премия МУЗ-ТВ 2019: самые сложные номера церемонии. Взято 18 октября 2020 г. из https://muz-tv.ru/news/premiya-muz-tv-2019-samyeslozhnye-nomera-ceremonii.

\section{- References}

Bodnarchuk, O. V. (2020). Kak sozdat' grandioznoe shou [How to create a grand show]. Bezuglii M. O. FOP [in Russian].

Boiko, O. S. (2017). Televiziini tantsiuvalni shou v Ukraini: istoriia i suchasnist [Television dance shows in Ukraine: history and modernity]. Bulletin of Kyiv National University of Culture and Arts. Series in Arts, 36, 66-76 [in Ukrainian].

Dubovik, N. (n.d.). Shoutizatsiya sovremennoi kul'tury [Showtization of modern culture]. DOKPLAYER, 224-233. Retrieved Oktober 20, 2020, from https://docplayer. ru/36670939-Shoutizaciya-sovremennoy-kultury.html [in Russian].

Hitti, N. (2018, May 9). Giant augmented reality avatar of Bono appears on Es Devlin's U2 stage set. Dezeen. https://www.dezeen.com/2018/05/09/es-devlin-augmentedreality-avatar-bono-u2-set-design/ [in English]. 
Kyrylenko, K., Kunderevych, O., \& Boiko L. (2018). Filosofiia kultury [Philosophy of Culture]: Dictionary. Ahentstvo "Ukraina " [in Ukrainian].

Madonna. (2020, February 1). Madonna \& Maluma - Medellín (2019 Billboard Music Awards) [Video]. YouTube. https://www.youtube.com/watch?v=9Z1GdMuC9E8 [in English].

Mikhailov, L. N. (2007). Sozdanie sovremennogo estradnogo zrelishcha: printsipy khudozhestvennogo oformleniya [Creating a modern variety show: principles of decoration] [Abstract of PhD Dissertation, Russian Academy of Theater Arts] [in Russian].

Millman, E. (2020, June 16). BTS Just Proved That Paid Livestreaming Is Here to Stay. RollingStone. https://www.rollingstone.com/pro/news/bts-paid-livestream-bangbang-con-1015696/ [in English].

Mozhenko, M. V., \& Priadko, O. M. (2018). Virtualna realnist: vid tekhnolohii do mystetstva [Virtual reality: from technology to art]. Notes on Art Criticism, 34, 112-122 [in Ukrainian].

Murtazina, M. Sh. (2012). Virtual'naya kul'tura kak fenomen globalizatsii: filosofskokul'turologicheskoe osmyslenie [Virtual Culture as a Phenomenon of Globalisation: Philosophical and Cultural Understanding] [Abstract of PhD Dissertation, "Transbaikal State University"] [in Russian].

Muz-tv. (n.d.). Premiya MUZ-TV 2019: samye slozhnye nomera tseremonii [MUZ-TV award 2019: the most difficult numbers of the ceremony]. Retrieved Oktober 18, 2020, from https://muz-tv.ru/news/premiya-muz-tv-2019-samye-slozhnye-nomeraceremonii [in Russian].

Press-sluzhba Orgkomiteta 45-go mirovogo chempionata WorldSkills Kazan 2019. (2019, August 22). Roboty, kity i klyatvy: v Kazani proshla tseremoniya otkrytiya 45-go mirovogo WorldSkillsKazan 2019 [Robots, whales and vows: the opening ceremony of the 45 ${ }^{\text {th }}$ World WorldSkillsKazan 2019]. https://worldskills2019.com/ru/media/ news/roboty-kity-i-klyatvy-v-kazani-proshla-ceremoniya-otkrytiya-45-go-mirovogoworldskills-kazan-2019/index.html [in Russian].

Skrypka, A. O. (2010). Shou-tekhnolohii yak forma sotsialnoi komunikatsii [Show technologies as a form of social commune] [Abstract of PhD Dissertation, V. N. Karazin Kharkiv National University] [in Ukrainian].

Sovhyra, T. I. (2014). Shou yak forma orhanizatsii masovoho dozvillia [Shows as a form of mass leisure organization]. Perspektyvni napriamky svitovoi nauky, 1, 65-67 [in Ukrainian].

Stanislavska, K. I. (2016). Mystetsko-vydovyshchni formy suchasnoi kultury [Art and entertainment forms of modern culture] [Monograph] ( $2^{\text {nd }}$ ed). National Academy of Culture and Arts Management [in Ukrainian].

Tikhonovskaya, G. S. (2016). Tekhnologicheskie aspekty realizatsii elementa zrelishchnosti v kul'turno-dosugovykh programmakh [Technological aspects of the implementation of the element of entertainment in cultural and leisure programs]. Vestnik Moskovskogo gosudarstvennogo universiteta kul'tury i iskusstv, 5(73), 155-163 [in Russian].

Virtualna realnist [Virtual reality]. (2020, April 5). In Wikipedia. https://cutt.ly/ghGsTmh [in Ukrainian]. 
Volynets, V. O. (2019). Virtualizatsiia kultury v dobu internet-tekhnolohii [Virtualisation of culture in the age of Internet technologies] [Abstract of PhD Dissertation, Kyiv National University of Culture and Arts] [in Ukrainian].

Yudova-Romanova, K. V. (2017). Tekhnichni zasoby oformlennia stsenichnoho prostoru [Technical means of registration of stage space]. Vydavnychyi tsentr KNUKiM [in Ukrainian].

Yudova-Romanova, K., Strelchuk, V., \& Chubukova, Yu. (2019). Rezhyserski innovatsii u vykorystanni tekhnichnykh zasobiv i tekhnolohii u stsenichnomu mystetstvi [Directing innovations in the use of technical means and technologies in the performing arts]. Bulletin of Kyiv National University of Culture and Arts. Series in Stage Art, 2(1), 52-57 [in Ukrainian].

Zmishana realnist [Mixed reality]. (2020, May 20). In Wikipedia. https://cutt.ly/ShFToS4 [in Ukrainian].

\section{VIRTUAL REALITY TECHNOLOGY FOR CONTEMPORARY CONCERT SHOWS}

\section{- Alyona Kyrychenko}

- PhD student, ORCID: 0000-0002-6237-832X, e-mail: AlenaKiri4enko@gmail.com, Kyiv National University of Culture and Arts, Kyiv, Ukraine

\section{- Abstract}

The purpose of the article is to characterise contemporary concert shows in the context of virtual reality technology. The research methodology is based on the application of an interdisciplinary approach to the analysis of concert shows; the theoretical approach is to study scientific literature; analytical and comparative are to determine the influence of the technological component on the direction of contemporary shows. The scientific novelty lies in the fact that virtual technology integrated into a concert show is considered for the first time. Conclusions. Virtual/augmented reality technology, gradually entering all spheres of our life: from medicine, education, science to art, architecture and human leisure activities, are no longer associated with super-critical one. A concert show applying advanced technologies can combine different types of art, and therefore has a powerful potential to influence the viewer. On the example of specific concert shows and performances of artists, the article highlights the mechanism of "weaving" of virtual/augmented reality technology into the stage space. The concept of virtual, augmented, and mixed reality is considered. It is indicated that with the powerful development of information and communication technologies, it is possible to combine all computer technology into a single augmented reality. The end of the twentieth century was marked by the emergence of a virtual band, and already at the beginning of the $21^{\text {st }}$ century, there were virtual vocaloid artists and the reproduction of virtual copies of deceased artists, which gives grounds to state the possibility of introducing the latest computer technology into concert shows. Attention is focused on the fact that the use of technology not only becomes 
"effect for the sake of effect", but also emphasises or complements the ideological and thematic scope of the show. The creation of virtual online concerts and shows by Ukrainian and foreign artists has become an outstanding milestone in the entertainment industry of our time. The concert shows are being transformed under the influence of virtual technology; that is, they are virtualised to be relevant and meet the challenges of the time and the demands of a demanding audience.

Keywords: concert show; VR / AR / MR / XR; vocaloid; virtual online concert; entertainment industry

\section{ИСПОЛЬЗОВАНИЕ ТЕХНОЛОГИЙ ВИРТУАЛЬНОЙ РЕАЛЬНОСТИ В СОВРЕМЕННЫХ КОНЦЕРТНЫХ ШОУ}

\section{- Кириченко Алена Олеговна}

\section{Аспирантка,}

ORCID: 0000-0002-6237-832X, e-mail: AlenaKiri4enko@gmail.com, Киевский национальный университет культуры и искусств, Киев, Украина

\section{Аннотация}

Цель статьи - охарактеризовать современные концертные шоу в контексте использования в них технологий виртуальной реальности. Методология исследования основана на применении междисциплинарного подхода к анализу концертных шоу, теоретического подхода - для изучения научной литературы; аналитического и компаративного - для определения влияния технологической составляющей на режиссуру современных шоу. Научная новизна заключается в том, что впервые рассмотрены виртуальные технологии, интегрированные в концертное шоу. Выводы. Технологии виртуальной / дополненной реальности, постепенно входя во все сферы нашей жизни: от медицины, образования, науки - до искусства, архитектуры и досуговой деятельности человека, уже перестают ассоциироваться с чем-то сверхновым. Концертное шоу с помощью современных технологий может сочетать в себе разные виды искусства, а потому владеет мощным потенциалом влияния на зрителя. На примере конкретных концертных шоу и выступлений артистов представлен механизм «вплетения» технологий виртуальной / дополненной реальности в сценическое пространство. Рассмотрены понятия виртуальной, дополненной и смешанной реальности. Указано, что с мощным развитием информационно-коммуникационных технологий возможно сочетание всех компьютерных технологий в единой расширенной реальности. Конец XX в. ознаменовался появлением виртуальной группы, а уже начало XXI в. - появлением виртуальных артистов-вокалоидов и воспроизведением виртуальных копий умерших артистов, что дает основания констатировать возможности внедрения новейших компьютерных технологий в концертные шоу. Акцентируется внимание на том, что использование технологий становится не только «эффектом ради эффекта», но и подчеркивает или дополняет идейно-тематическую направленность 
шоу. Выдающимся событием в индустрии развлечений современности стало создание украинскими и зарубежными артистами виртуальных онлайн-концертов и шоу. Концертные шоу трансформируются под влиянием виртуальных технологий, то есть виртуализируются, чтобы быть актуальными и соответствовать вызовам времени и запросам требовательной зрительской аудитории.

Ключевые слова: концертное шоу; VR / AR / MR / XR; вокалоид; виртуальный онлайн-концерт; индустрия развлечений 